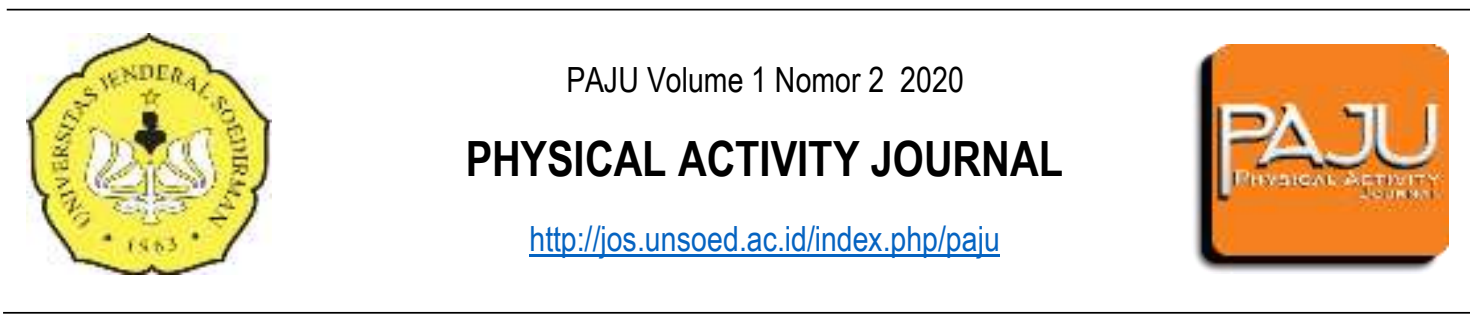

\title{
Perbedaan Kepercayaan Diri Pada Siswa yang Mengikuti Ekstrakurikuler Olahraga
}

\author{
${ }^{1}$ Andri Kamnuron, ${ }^{2}$ Yusuf Hidayat, ${ }^{3}$ Nuryadi \\ 1SMA Negeri 1 Jatinangor Sumedang, Indonesia \\ 2,3Prodi. PJKR FPOK Universitas Pendidikan Indonesia Bandung, Indonesia \\ email: ${ }^{1}$ kamnuron@gmail.com \\ DOI: https://doi.org/10.20884/1.paju.2020.1.2.2394
}

\begin{abstract}
Abstrak
Prestasi dalam olahraga dapat ditingkatkan apabila seseorang memiliki rasa percaya diri yang baik, terutama pada olahraga beregu maupun olahraga perorangan. Oleh karena itu penting untuk mengkaji tingkat kepercayaan diri yang dimiliki oleh atlet cabang olahraga beregu ataupun cabang olahraga perorangan. Tujuan dari penelitian ini yaitu untuk membandingkan tingkat kepercayaan diri siswa yang mengikuti ekstrakurikuler olahraga beregu dengan siswa yang mengikuti ekstrakurikuler olahraga perorangan. Metode pada penelitian ini mengguakan metode deskrptif dengan instrumen peneliitan berupa angket kepercayaan diri. Populasi dan sampel berjumlah 30 orang dengan rincian siswa-siswi yang mengikuti ekstrakurikuler cabang olahraga beregu sepak bola berjumlah 15 orang dan siswa-siswi yang mengikuti ekstrakurikuler olahraga perorangan karate berjumlah 15 orang. Hasil analisis menunjukan bahwa siswa yang mengikuti ekstrakurikuler beregu dan perorangan memiliki tingkat kepercayaan diri yang baik, akan tetapi siswa yang mengikuti ekrakurikuler olaraga beregu sepak bola meiliki tingkat kepercayaan diri yang lebih baik dibandingkan dengan siswa yang mengikuti ekstrakurikuler olahraga perorangan karate. Kesimpulan penelitian ini yaitu tidak tedapat perbedaan yang signifikan pada tingkat percaya diri pada siswa ekstrakurikuler olahraga beregu maupun perorangan di SMAN 1 Jatinangor. Saran dari penelitian ini rasa percaya diri perlu dimiliki dan ditingkatkan pada diri siswa untuk menunjang prestasi yang diperoleh pada bidang pendidikan maupun olahraga.
\end{abstract}

Kata kunci: Kepercayaan Diri, Ekstrakurikuler, Olahraga Beregu, Olahraga Perorangan

\begin{abstract}
Achievement in sports can be improved if a person has good self-confidence, especially in team sports and individual sports. Therefore it is important to examine the level of confidence possessed by athletes in team sports or individual sports. The purpose of this study is to compare the level of self confidence of students who take team sports extracurricular activities with students who take individual sports extracurricular activities. The method in this research uses descriptive method with research instruments in the form of self-confidence questionnaire. The population and sample numbered 30 people with details of students who took part in the extracurricular branch of the football team sports amounted to 15 people and students who took extracurricular activities in karate individual sports numbered 15 people. The results of the analysis show that students who take team and individual extracurriculars have a good level of confidence, but students who take extracurricular football team sports have better levels of self-confidence compared to students who take karate individual sports extracurriculars. The conclusion of this study is that there is no significant difference in the level of confidence in
\end{abstract}


extracurricular team sports and individual students in Jatinangor 1 Public High School. Suggestions from this research self-confidence need to be owned and improved in students to support the achievements obtained in education and sports.

Keywords : Confidence, Extracurricular, Team Sports, Individual Sports

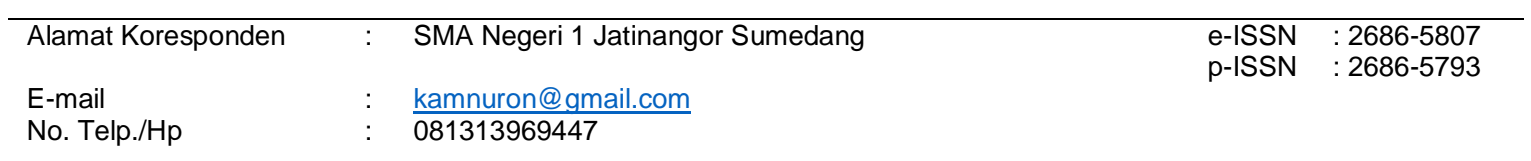

\section{PENDAHULUAN}

Olahraga pada perkembangannya menjadi salah satu kebutuhan yang penting bagi setiap orang. Dengan olahraga, seseorang akan dapat memperoleh manfaat berupa kesehatan, kesenangan, prestasi dan juga ilmu pengetahuan melalui proses pendidikan. Berdasarkan UU SKN (2005) dijelaskan bahwa ruang lingkup kegiatan olahraga meliputi olahraga pendidikan, rekreasi dan prestasi. Berdasarkan penjelasaan tersebut jelas bahwa olahraga menjadi kegiatan yang wajib dan penting untuk dilakukan oleh setiap kalangan masyarakat, terutama olarhraga yang dilaksanakan melalui proses pendidian.

Olahraga pendidkian merupakan kegiatan olahraga yang dilakukan di lingkungan pendidikan dan dimulai dari Sekolah Dasar hingga Sekolah Menegah Atas, dengan tujuan membentuk karakter kepada generasi muda melalui aktivitas pendidikan jasmani. Faozi et al. (2019) menjelaskan pendidikan jasmani merupakan jenis aktivitas fisik yang dilakukan secara sadar dan sistematik dalam rangka memperoleh kemampuan dan keterampilan jasmani, pertumbuhan, kecerdasan, emosional, dan pembentukan watak.

Olahraga pendidikan dalam bentuk pendidikan jasmani yang dilakukan di sekolah, pada prakteknya dilakukan melalui dua jenis kegiatan, yaitu intakurikuler dan ekstrakurikuler olahraga. Ekstrakurikuler olahraga merukapan kegiatan tambahan yang diselenggarakan di luar jam pelajaran pendidikan jasmani di sekolah. Subarkah et al. (2017) Ekstrakurikuler merupakan kegiatan pembelajaran di luar kegiatan intrakurikuler yang diselenggarakan untuk pembentukan karakter pada siswa.

Kegiatan ekstrakurikuler olahraga yang dilaksanakan di sekolah memiliki tujuan untuk mengembangkan potensi dan bakat siswa di bidang olahraga, khususnya olahraga prestasi pada tingkat pelajar. Suparyo (2017) menjelaskan tujuan diselenggarakannya kegiatan ekstrakurikuler bidang olahraga diharapkan dapat memberikan pengaruh terhadap minat, bakat dan potensi yang dimiliki oleh siswa. Kegiatan ekstrakurikuler olahraga yang dilaksanakan di sekolah memiliki dua jenis olahraga yaitu olahraga beregu dan olahraga perorangan.

Olahraga beregu yang diminati dalam kegiatan ekstrakurikuler olahraga salah satunya yaitu sepak bola. Qohhar \& Pazriansyah (2019) menjelaskan permainan sepakbola yang dikembangkan dalam kurikulum pendidikan jasmani dilaksanakan melalui program intrakurikuler maupun ekstrakurikuler. Sepak bola menjadi salah satu kegiatan ekstrakurikuler olahraga yang digemari oleh siswa, dan pada 
perkembangannya tidak hanya siswa putra saja yang terlibat akan tetapi siswa putri juga sudah mulai mengkuti kegiatan ekstrakurikuler sepak bola tersebut.

Selain sepak bola, ekstrakurikuler olahraga perorangan juga menjadi salah satu jenis ekstrakurikuler yang diminati oleh siswa, khusunya ekstrakurikuler karate. Olahraga karate banyak diikuti oleh siswa karena dapat menumbuhkan sikap positif dalam diri selain juga prestasi. Minati \& Wisnu (2016) menjelaskan Karate dapat menumbuhkembangkan jiwa kemandirian, sportivitas, satria dan disiplin, membentuk fisik yang sehat, kuat dan menguasai beladiri, juga untuk menuju prestasi tingkat daerah, nasional dan Internasional.

Ekstrakurikuler beregu cabang olahraga sepak bola dan ekstrakurikuler perorangan cabang olahraga karate merupakan dua kegiatan ekstrakurikuler yang hampir dilaksanakn di setiap sekolah khususnya Sekolah Menegah Atas (SMA) karena dengan mengikuti kegiatan ekstrakurikuler tersebut, siswa dapat mengembangkan minat, bakat, prestasi dan menumbuhkan rasa percaya diri. Percaya diri merupakan komponen psikologis yang penting untuk dapat meningkatkan kemampuan dan prestasi di bidang olahraga.

Kepercayaan diri merupakan kemampuan dalam diri seseorang mengenai keyakinan akan potensi yang ada dalam dirinya sehingga tidak mudah terpengaruh oleh orang lain (Ghufron \& Risnawati, 2010). Lebih lanjut Pamungkas \& Fakhrurrozi (2010) kepercayaan diri adalah kepercayaan akan kemampuan sendiri serta dapat memanfaatkannya dengan tepat. Kepercayaan diri dibutuhkan oleh siswa untuk dapat menjalankan program ekstrakurikuler dengan baik, sehingga dapat mendukung dalam pencapaian prestasi pada cabang olahraga. Hasil penelitian terdahulu menunjukan untuk dapat berprestasi tinggi, atlet harus memiliki rasa percaya diri dalam dirinya (Effendi, 2016).

Penelitian kepercayaan diri siswa berdasarkan kegiatan ekstrakurikuler olahraga yang diikuti, perlu dilakukan karena dengan penelitian ini akan diketahui tingkat kepercayaan diri yang dimiliki oleh siswa, sehingga dapat menjadi acuan bagi lembaga dalam hal ini sekolah untuk mendorong sisiwa terlibat aktif dalam berbagai kegiatan ekstrakurikuler olahraga di sekolah. Pembinaan dan pengembangan olahraga pendidikan di sekolah dilaksanakan untuk mengembangkan bakat, minat dan kepribadian yang dimiliki oleh siswa (UU SKN, 2005).

Hasil penelitian terdahulu menujukan bahwa dengan mengikuti kegiatan ekstrakurikuler olahraga, siswa dapat meningkatkan keterampilan dan sikap sosial yang dimiliki (Pamungkas et al., 2019), hasil penelitian ini juga didukung oleh UU SKN (2005) yang menjelaskan bahwa untuk menumbuhkembangkan prestasi olahraga di lembaga pendidikan, pada setiap jalur pendidikan dapat dibentuk unit kegiatan olahraga. Penelitian lain yang dilakukan oleh Setiawan \& Rahmat (2018) menunjukan hasil kegiatan ekstrakurikuler bola tangan dapat meningkatkan sikap sosial siswa. Sehingga dampak kegiatan eksrakurikuler terhadap sikap sosial dalam hal ini rasa percaya diri perlu diteliti. 
Kajian mengenai tingkat kepercayaan diri memang sudah banyak di lakukan, akan tetapi pada penelitian ini memiliki beberapa perbedaan dengan penelitian sebelumnya, yaitu dalam penelitian ini lebih menekankan pada kajian mengenai tingkat kepercayaan diri pada siswa yang mengikuti kegiatan ekstrakurikuler berbeda yaitu olahraga beregu dan perorangan, sehingga hasilnya nanti dapat diketahui perbandingan tingkat kepercayaan diri antara keduanya. Selain itu di SMAN 1 Jatinangor, Kabupaten Sumedang belum pernah dilakukan kajian mengenai tingkat kepercayaan diri siswa yang mengikuti kegiatan ekstrakurikuler olahraga, padahal kepercayaan diri merupakan komponen penting untuk dapat bersaing dan berprestasi di dunia pendidikan maupun olahraga.

Berdasarkan kajian tersebut maka, perlu adanya kajian mendalam mengenai tingkat kepercayaan diri yang dimiliki oleh siswa peserta ekstrakurikuler di Sekolah Menegah Atas (SMA) Negeri 1 Jatinangor, khususnya pada cabang olahraga beregu sepak bola dan ekstrakurikuler cabang olahraga perorangan karate. Sehingga tujuan dari penelitian ini yaitu untuk mengetahui tingkat kepercayaan diri pada siswa yang mengikuti kegiatan ekstrakurikileh olahraga beregu sepak bola dengan siswa yang mengikuti kegiatan ekstrakurikuler olahraga perorangan karate untuk diketahui perbedaan dan manfaat dari kegiatan ekstrakurikuler tersebut.

\section{METODE}

Penelitian ini menggunakan metode deskriptif, (Nazir, 2005) Metode deskriptif adalah suatu metode dalam meneliti status kelompok manusia, suatu objek, suatu set kondisi, suatu system pemikiran, ataupun suatu kelas peristiwa pada masa sekarang. Populasi dan sampel pada penelitian ini yaitu siswa yang mengikuti ekstrakurikuler sepak bola dengan jumlah 15 siswa dan ekstrakurikuler karate dengan jumlah 15 siswa. Teknik sampling yang digunakan yaitu Purposive Random Sampling, teknik pengambilan sampel dengan menentukan sampel berdasarkan kriteria tertentu, yaitu jenis kelamin lakilaki, siswa kelas X dan XI SMAN 1 Jatinangor, mengikuti ekstrakurikuler sepak bola dan ekstrakurikuler karate, kemudian dilakukaan pengundian secara acak untuk mendapatkan jumlah sampel tersebut di masing-masing kelompok.

Instrumen yang digunakan pada penelitian ini berupa angket atau kuisioner dengan menggunakan skala Likert (Sugiyono, 2016). Instrumen angket kepercayaan diri berdasarkan (Lauster, 1992) dalam (Ghufron \& Risnawati, 2010) dengan reliabilitas sebesar 0,88 dengan kategori tinggi.

Tabel 1. Kategori Tingkat Kepercayaan Diri

\begin{tabular}{cl}
\hline Interval & Katagori \\
\hline$x<(\mu-1,0 \sigma)$ & Rendah \\
\hline$(\mu-1,0 \sigma \leq x<(\mu+1,0 \sigma)$ & Sedang \\
\hline$(\mu+1,0 \sigma) \leq x$ & Tinggi \\
\hline
\end{tabular}


HASIL

Hasil pengolahan data variabel penelitian pada tingkat kepercayaan diri siswa yang mengikuti ekstrakurikuler olahraga beregu (sepak bola) dengan siswa yang mengikuti ekstrakurikuler olahraga perorangan (karate).

\section{a. Tingkat Kepercayaan Diri Siswa yang Mengikuti Ekstrakurikuler Beregu Sepak Bola}

Hasil pengolahan data pada tingkat kepercayaan diri siswa yang mengikuti kegiatan ekstrakurikuler olahraga beregu sepak bola dan ekstrakurikuler olahraga perorangan karate di SMAN 1 Jatinangor dapat di lihat pada tabel 2 dan 3 di bawah ini.

Tabel 2. Tingkat Kepercayaan Diri Siswa yang Mengikuti Ekstrakurikuler

\begin{tabular}{llllll}
\hline \multicolumn{6}{c}{ Group Statistics } \\
\hline Kepercayaan diri & olahraga beregu & $\mathbf{N}$ & Mean & Std. Deviation & Std. Error Mean \\
\hline \multirow{2}{*}{ Kepercayaan diri } & olahraga Perorangan & 15 & 151.33 & 7.715 & 1.992 \\
\hline
\end{tabular}

Tabel 3. Hasil Perhitungan Kriteria Kepercayaan Diri Siswa

\begin{tabular}{cccc}
\hline Interval & Katagori & $\begin{array}{c}\text { Olahraga Beregu } \\
\text { Sepak Bola }\end{array}$ & $\begin{array}{c}\text { Olahraga Perorangan } \\
\text { Karate }\end{array}$ \\
\hline$x<84$ & Rendah & 0 & 0 \\
\hline $84 \leq x<132$ & Sedang & 0 & 0 \\
\hline $132 \leq x$ & Tinggi & 15 & 15 \\
\hline
\end{tabular}

Berdasarkan data tersebut di atas menunjukan bahwa kepercayaan diri siswa yang mengikuti ekstrakurikuler olahraga beregu sepak bola memiliki rata-rata sebesar 151.33, sedangkan utuk rata-rata skor tingkat kepercayaan diri siswa yang mengikuti ekstrakurikuler olahraga perorangan karate adalah sebesar 148.73. Hal ini berarti bahwa tingkat kepercayaan diri siswa yang mengikuti kedua ekstrakurikuler tersebut tergolong pada kategori tinggi.

b. Perbandingan Skor Rata-Rata

Hasil perbandingan skor rata-rata tingkat kepercayaan diri siswa yang mengikuti kegiatan ekstrakurikuler olahraga beregu sepak bola dengan ekstrakurikuler olahraga perorangan karate di SMAN 1 Jatinangor dapat di lihat pada gambar 1 di bawah ini. 


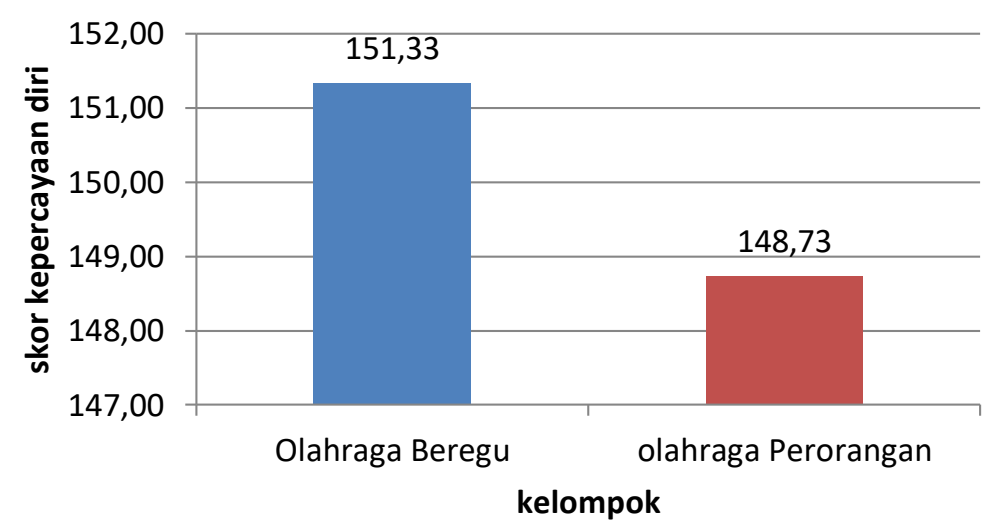

\section{Gambar 1. Perbandingan skor rata-rata tingkat kepercayaan diri siswa}

Berdasarkan gambar diagram di atas diketahui bahwa tingkat kepercayaan diri siswa yang mengikuti ekstrakurikuler olahraga beregu sepak bola lebih baik daripada kepercayaan diri siswa yang mengikuti ekstrakurikuler olahraga perorangan karate, walaupun selisih di antara keduanya tidak terlalu signifikan yaitu hanya 2.6 poin.

\section{PEMBAHASAN}

Berdasarkan hasil analisis data menunjukan tidak terdapat perbedaan yang signifikan pada tingkat kepercayaan diri siswa yang mengikuti ekstrakurikuler olahraga beregu (sepak bola) dan yang mengikuti ekstrakurikuler olahraga perorangan (karate) di SMAN 1 Jatinangor. Hasil penelitian juga menunjukan tingkat kepercayaan diri siswa yang mengikuti ekstrakurikuler olahraga beregu (sepak bola) dan ekstrakurikuler perorangan (karate) pada umumnya memiliki kepercayaan diri yang baik dan sebagian besar berada dalam kategori tinggi. Akan tetapi hasil kepercayaan diri siswa yang mengikuri ekstrakurikuler sepak bola lebih baik daripada ekstrakurikuler karate. Tujuan dari kegiatan ekstrakurikuler yaitu untuk mengembangkan kemampuan, kepribadian dan bakat di bidang non akademik (Pamungkas et al., 2019)

Tingkat kepercayaan diri siswa yang mengikuti ekstrakurikuler karate berada pada kategori baik, hal ini dikarenakan karate merupakan salah satu olahraga beladiri yang lebih mengutamakan kedisiplinan, keberanian, sportivitas/kejujuran, kewaspadaan, rasa sosial, antisipasi, kepercayaan diri dan pengendalian emosi. Olahraga bela diri juga memiliki kelebihan dalam membina jiwa/mental, yang membedakan dari jenis olahraga lainya. Hasil ini mendukung penelitian sebelumnya bahwa atlet cabang olahraga beladiri taekwondo memiliki tingkat kepercayaan diri yang baik dengan disertai dukungan sosial yang tepat (Sakti \& Rozali, 2015). 
${ }^{1}$ Andri Kamnuron, ${ }^{2}$ Yusuf hidayat, ${ }^{3}$ Nuryadi/ PAJU : Physical Activity Journal 1 (2) (2020)

Ekstrakurikuler olahraga beregu (sepak bola) merupakan olaharaga yang dituntut untuk bekerjasama sehingga penangananya sangat komplek dari latihan yang diterapakan juga berbeda dibandingkan olahraga perorangan, bukan hanya latihan individual seperti latihan fisik dan teknik tapi juga latihan taktik bagaimana supaya atlet bisa memiliki keyakinan terhadap dirinya ketika bermain bersama rekan-rekannya dalam sebuah tim. Dilihat dari rata-rata olahraga beregu sedikit lebih baik kepercayaan dirinya dikarenakan dalam kelompok atau olahraga beregu seperti ada beberapa individu yang berinteraksi dan saling tergantung untuk mencapai tujuan bersama, dan ada pula prasysarat nonfisik, seperti presepsi sebagai satu kesatuan serta perasaan sebagai bagaian dari kelompok olahraga tersebut. Ini mendukung pendapat dari (Elisabet, 2010) menjelaskan manfaat kelompok bagi individu yaitu (1) Kelompok memenuhi kebutuhan individu untuk merasa berarti dan dimiliki, (2) Kelompok sebagai sumber identitas diri, (3) Kelompok sebagai sumber informasi tentang dunia dan tentang diri kita.

Dari pendapat di atas dapat dikatakan bahwa dalam mengikuti ekstrakurikuler olahraga beregu memilliki keyakinan terhadap dirinya bahwa dengan berkelompok memliki pandangan lebih baik terhadap dirinya dibandingkan dengan berdiri sendiri atau individual dengan adanya kerjasama dalam tim menumbuhkan kepercayaan diri dari setiap individu dalam tim. Kepercayaan diri siswa/atlet tidak hanya di tunjang dari latihan olahraga beregu atau olahraga perorangan saja tapi dari segi pengalaman atlet mengikuti pertandingan, semakin atlet sering bertanding semakin meningkat kepercayaan dirinya. (Anthony,1992) dalam (Ghufron \& Risnawati, 2010) bahwa pengalaman dapat menjadi faktor munculnya rasa percaya diri, sebaliknya, pengalaman juga dapat menjadi faktor menurunya rasa percaya diri seseorang. Sejalan dengan hal itu siswa yang mengikuti ekstrakurikuler olahraga untuk mencapai tujuan yang di harapkan yaitu prestasi perlu adanya pengalaman bertanding dalam suatu kejuaraan tidak hanya proses latihan tanpa adanya pengalaman bertanding.

Berdasarkan hasil analisis yang di lakukan, terbukti tidak ada perbedaan yang signifikan antara tingkat kepercayaan diri siswa yang mengikuti ekstrakurikuler olahraga beregu (sepak bola) dengan perorangan (karate). Sesuai dengan hasil uji independent samples tes di atas, didapat signifikasi sebesar 0,541. Karena nilai signifikansi lebih besar dari 0,05 $(0,541>0,05)$. Berarti dapat disimpulkan bahwa tidak ada perbedaan yang signifikan tingkat kepercayaan diri siswa yang mengikuti ekstrakurikuler sepak bola dan karate. Ini terbukti dari nilai rata-rata kepercayaan diri siswa ekstrakurikuler olahraga beregu (sepak bola) yaitu 151,33 sedangkan ekstrakurikuler olahraga perorangan (karate) yaitu 148,73 tidak berbeda jauh atau berselisih sekitar 2,6 poin sehingga tidak ada perbedaan yang signifikan antara ekstrakurikuler olahraga beregu dengan olahraga perorangan.

Berdasarkan hasil penelitian menunjukan bahwa di SMAN Jatinangor, siswa yang mengikuti ekstrakurikuler olahraga sepakbola dengan siswa yang mengikuti ekstrakurikuler olahraga karate memiliki tingkat kepercayaan diri yang hampir sama. Hal ini disebabkan karena kedua kegiatan 
ekstrakurikuler tersebut mampu meningkatkan rasa percaya diri pada siswa, dengan melakukan kegiatan olahraga baik secara berkelompok maupun individu/perorangan akan membuat motivasi anak meningkat sehingga mampu melakukan berbagai keterampilan dengan baik dan meningkatkan kepercayaan diri pada siswa.

\section{SIMPULAN}

Kepercayaan diri siswa yang terlibat dalam kegiatan ekstrakurikuler olahraga beregu sepak bola dan ekstrakurikuler olahraga perorangan karate berada pada tinngkat kategori tinggi, sehingga mereka memiliki kepercayaan diri yang baik. Berdasarkan hasil penelitian dapat disimpulkan bahwa tidak terdapat perbedaan yang siginifikan tingkat kepercayaan diri siswa yang mengikuti ekstrakurikuler olahraga beregu dengan siswa yang mengikuti ekstrakurikuler olahraga perorangan di SMAN 1 Jatinangor Kabupaten Sumedang. Karena kegiatan ekstrakurikuler olahraga merupakan salah satu faktor penting untuk mengembangakn keterampilan dan sikap sosial, terutama percaya diri, maka disarankan siswa/siswi untuk mengikuti kegiatan salah satu ekstrakurikuler olahraga yang diselenggarakan di sekolah.

\section{REFERENSI}

Effendi, H. (2016). Peranan psikologi olahraga dalam meningkatkan prestasi atlet. Nusantara (Jurnal IImu Pengetahuan Sosial. https://doi.org/http://jurnal.umtapsel.ac.id/index.php/nusantara/article/view/90/90

Elisabet, H. (2010). Psikologi Perkembangan Suatu Pendekatan Sepanjang Rentang Hidup. In Erlangga.

Faozi, F., Sanusi, H., \& Listiandi, A. (2019). Pengaruh Model Pembelajaran Kooperatif Tipe Stad Terhadap Keterampilan Passing Bawah Dalam Permainan Bola Voli Di SMA Islam AlFardiyatussa'adah Citepus Palabuhanratu. Physical Activity Journal, 1(1), 51-60. https://doi.org/10.32424/1.paju.2019.1.1.2001

Ghufron, \& Risnawati. (2010). Teori-Teori Psikologi. Ar-ruzz Media.

Minati, M., \& Wisnu, H. (2016). Hubungan Antara Dukungan Orang Tua Dengan Minat Siswa Mengikuti Ekstrakurikuler Karate Di Smp Negeri 2 Taman Sidoarjo. Jurnal Pendidikan Olahraga Dan Kesehatan, 4(2), 313-320.

Nazir, M. (2005). Metode Penenlitian. Ghalia Indonesia.

Pamungkas, A. A., \& Fakhrurrozi, M. (2010). Persepsi Terhadap Cidera Dan Kepercayaan Diri Pada Atlet Tae Kwon Do Wanita. Jurnal Psikologi, 3(2).

Pamungkas, H. J., Festiawan, R., \& Nurcahyo, P. J. (2019). Pengaruh Latihan Small Side Game Terhadap Kemampuan Long Pass Pada Peserta Ekstrakurikuler Sepakbola. Media IImu Keolahragaan 
Indonesia, 9(1).

Qohhar, W., \& Pazriansyah, D. (2019). Pengaruh Model Pembelajaran Kooperatif Tipe Teaching Games For Understanding (TGFU) Terhadap Peningkatan Hasil Belajar Teknik Dasar Sepakbola. Physical Activity Journal, 1(1), 27-35. https://doi.org/doi:10.32424/1.paju.2019.1.1.1998

Sakti, G., \& Rozali, Y. (2015). Hubungan Dukungan Sosial Dengan Kepercayaan Diri Pada Atlet Cabang Olah Raga Taekwondo Dalam Berprestasi (Studi Pada Atlet Taekwondo Club BJTC, Kabupaten Tanggerang). Jurnal Psikologi.

Setiawan, A., \& Rahmat, A. (2018). Pengaruh Pembelajaran Bola Tangan Terhadap Perilaku Sosial Siswa. Jurnal Pendidikan Jasmani dan Olahraga. https://doi.org/10.17509/jpjo.v3i1.10188

Subarkah, F., Sartono, H., \& Saputra, M. Y. (2017). Minat Dan Motif Siswi Mengikuti Ekstrakurikuler Olahraga Futsal Di Kota Bandung. Jurnal Kepelatihan Olahraga, 10(2).

Sugiyono, P. D. (2016). metode penelitian kuantitatif, kualitatif,dan R\&D. In Alfabeta, cv. Alfabeta.

Suparyo. (2017). Pengaruh Pembinaan Ekstrakurikuler dan Ketersediaan Sarana Prasarana Terhadap Pengembangan Olahraga: Studi Pada SMA Negeri Se-Kabupaten Majalengka. Indonesian Journal of Education Management and Administration Review, 1(1).

UU SKN. (2005). Undang-Undang Republik Indonesia Nomor 3 Tahun 2005. Republik Indonesia. 